\title{
Fuel distribution process risk analysis in East Borneo
}

\author{
Raizsa Laksmita* and Imam Djati Widodo \\ Industrial Engineering, Universitas Islam Indonesia, Yogyakarta, 55584, Indonesia
}

\begin{abstract}
Fuel distribution is an important aspect of fulfilling the customer's need. It is risky because it can cause tardiness that can cause fuel scarcity. In the process of distribution, many risks are occurring. House of Risk is a method used for mitigating the risk. It identifies seven risk events and nine risk agents. Matrix occurrence and severity are used for eliminating the minor impact risk. House of Risk 1 is used for determining the Aggregate Risk Potential (ARP). Pareto diagram is applied to prioritize risk that must be mitigated by preventive actions based on ARP. It identifies 4 priority risks, namely A8 (Car trouble), A4 (Human Error), A3 (Error deposit via bank and underpayment), and A6 (traffic accident) which should be mitigated. House of Risk 2 makes for mapping between the preventive action and risk agent. It gets the Effectiveness to Difficulty Ratio (ETD) for mitigating action. Conducting safety talk routine once every three days with ETD 2088 is the primary preventive actions.
\end{abstract}

\section{Introduction}

Supply chain management has an important role in every business process in a company because it influences efficiency and effectivity of relation to the supplier, manufacturer, and the customer. "Generally, all activities related to material flow, information flow, and financial flow along the supply chain are the activities within the scope of SCM" [1].

The supply chain is a set of firms that pass materials forward. Normally, several independent firms are involved in manufacturing a product and placing it in the hands of the end user in a supply chain. Raw material and component producers, product assemblers, wholesalers, retailer merchants and transportation companies are all members of a supply chain [2].

Every company's business activity, including supply chain, always has the risk that can disrupt the success of the company and even endanger the safety of worker [3]. Therefore, risk management is needed. British Standard Institute's Guide to project management defines risk management as "processes whereby decisions are made to accept a known or assessed risk or the implementation of action to reduce the consequences or the probability of occurrence of an adverse event" [4]. In the context of supply chain risk management, events are characterized by their probability of occurrence and their related consequences within the supply chain[5].

Supply chain risk management is not only as the cost Saving but rather a value creation activity has given that it can lead to more sustainable supply chains $[6,7]$.

The fuel distribution is an important process of fuel industry to deliver the fuel to the customer in the right quantity and on time. It is risky activity because if tardiness of delivering happens, it can cause fuel scarcity that endangers other related business. In the process of distribution, some potential risks can happen especially in filling and delivery process. Identifying risk and preventive action are needed for mitigating and minimizing the risks. Some risk analysis researches have been done in some aspect of oil and gas industries such as in financial $[8,9]$ and supply chain modeling $[10,11]$.

Delivery flexibility measures adopted by the firms are largely internal to the firm. Delivery or shipment risk is in not only to the internal process and distribution flexibility related aspects of the firm but also to the poor logistics infrastructure that is external to the firm.[12]

House of risk is a renewable method of risk analysis. It is modification of the Failure Mode and Effects Analysis (FMEA) method for quantification of risk by quantification and the House of Quality (HOQ) model to prioritize which risk agents should be addressed first and to select the most effective action to reduce Potential risks posed by risk agent [13]. Implementation house of risk in supply chain have been done by some researchers. Kusmantini et al. implemented House of Risk in Furniture supply chain risk [14]. Data collection uses a triangular method that combined in depth interview technique with a number of successful exporters and distributing questioners to more than 80 SMEs in DIY. It identifies 23 agents and 43 incidence risks in the supply chain. It is also implemented in the supply chain of shoe company. By using two phases of house of risk, Kristanto [15] identifies 27 risk events and 52 risk agents. It gets 6 mitigation actions.

Thus, the advantages of prevention and mitigation in the distribution process are crucial because if the risk occurs it will cause enormous losses. It encourages researchers to conduct research on the mitigation and preventive actions to overcome the risk. House of risk will

\footnotetext{
* Corresponding author: 13522169@students.uii.ac.id
} 
be implemented to identify and mitigate risks to minimize losses. This study is done in a national oil company in Balikpapan.

\section{Research Method}

This step is identifying and formulating problems for doing research that uses in identifying the problems that occurred in the process. Data are collected by observation and interview. A deep discussion is done to determine risk rating scale with the company. Firstly, it collects and processes the data. Collecting data consist of primary data and secondary data. Primary data consists of result of observation, result of interview, and a rating scale from the company. The secondary data consist of House of Risk Application. The rating scale of severity can be shown in the Table 1.

Table 1. Severity rank

\begin{tabular}{|c|c|c|}
\hline Rank & $\begin{array}{c}\text { Subjective } \\
\text { Estimate for } \\
\text { Severity }\end{array}$ & Description \\
\hline 1 & No impact & Insignificant \\
\hline 2 & Minor impact & Single small impact \\
\hline 3 & $\begin{array}{c}\text { Medium } \\
\text { impact }\end{array}$ & $\begin{array}{l}\text { Cause short-period } \\
\text { difficulties }\end{array}$ \\
\hline 4 & Major impact & $\begin{array}{l}\text { Causes long-period } \\
\text { difficulties }\end{array}$ \\
\hline 5 & $\begin{array}{l}\text { Catastrophic } \\
\text { impact }\end{array}$ & Directly affect highest rates \\
\hline
\end{tabular}

Before interviewing an expert, it should need the occurrence rating scale, the occurrence rating scale shown in Table 2.

Table 2. Occurrence rating scale

\begin{tabular}{|c|c|c|c|}
\hline Rank & $\begin{array}{c}\text { Subjective } \\
\text { Estimate of } \\
\text { Occurrence }\end{array}$ & \multicolumn{2}{|c|}{ Description } \\
\hline 1 & $\begin{array}{c}\text { Very } \\
\text { unlikely }\end{array}$ & $\begin{array}{c}\text { Very rare event } \\
\text { (very rarely) }\end{array}$ & $\begin{array}{c}\text { Occurs } 1 \\
\text { times a } \\
\text { year }\end{array}$ \\
\hline 2 & Improbable & $\begin{array}{l}\text { There is } \\
\text { indirect } \\
\text { evidence of } \\
\text { event (rarely) }\end{array}$ & $\begin{array}{l}\text { Occurs } \\
2-3 \\
\text { times a } \\
\text { year }\end{array}$ \\
\hline 3 & Moderate & $\begin{array}{l}\text { There is direct } \\
\text { evidence of } \\
\text { event } \\
\text { (sometimes) }\end{array}$ & $\begin{array}{c}\text { Occurs } \\
3-4 \\
\text { times a } \\
\text { year }\end{array}$ \\
\hline 4 & Probable & $\begin{array}{l}\text { There is strong } \\
\text { direct evidence } \\
\text { of the event } \\
\text { (often) }\end{array}$ & $\begin{array}{c}\text { Occurs } \\
4-5 \\
\text { times a } \\
\text { year }\end{array}$ \\
\hline 5 & $\begin{array}{c}\text { Very } \\
\text { Probable }\end{array}$ & $\begin{array}{c}\text { Event recurs } \\
\text { frequently } \\
\text { (Very Often) }\end{array}$ & $\begin{array}{l}\text { Occurs }> \\
5 \text { times a } \\
\text { year }\end{array}$ \\
\hline
\end{tabular}

Data analysis is started by identifying activities based on SCOR-model. SCOR-model is the product of the
Supply-Chain Council (SCC), an independent, not-forprofit, global corporation with membership open to all companies and organizations interested in applying and advancing the state-of-the-art in supply-chain management systems and practices. There are three process levels of SCOR, level-1 process is known as SCOR process and are defined for each element such as a producer or wholesaler in the supply chain [16].

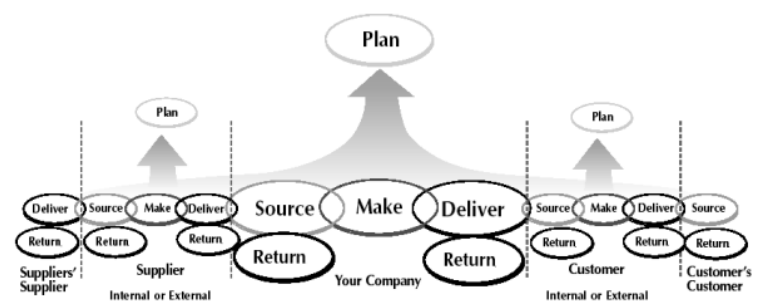

Fig. 1. SCOR Process (sources: supply chain council.inc. copyright 2016)

Occurrence and severity matrix is needed to eliminate the risk that has the minor impact. The matrix can be shown in Fig 2.

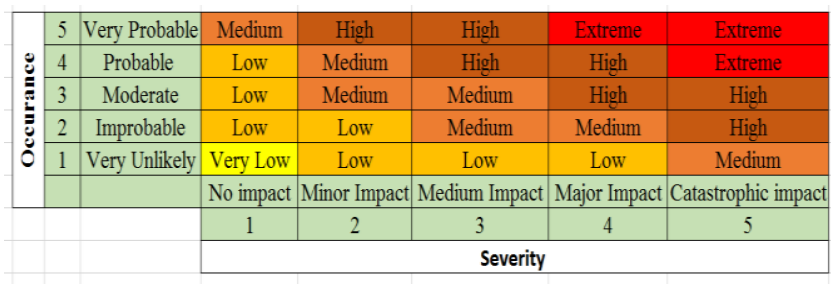

Fig. 2. Occurrence and severity matrix

The secondary data is the application of House of Risk 1 , House of risk phase one is trying to relate a set of requirements (what) and a set of responses (how) where each response could address one or more requirements. The degree of correlation is typically classified as none (and given an equivalent value of 0 ), low (one), moderate (three), and high (nine). Each requirement has a certain gap to fill and each response would require some types of resources and funds. In HOR 1 calculate the Aggregate Risk Potential (ARP). The formula of ARP is below:

$$
A R P j=O j \sum_{i} S i R i j
$$

where:

Oj: Occurrence $\{1,2,3,4,5\}$

Si: Severity $\{1,2,3,4,5\}$

Rij: Relationship between risk agent and risk event $\{0,1$, $3,9\}$

After making the HOR 1, Pareto analysis, based on the $\mathrm{ARP}$, is run to identify risk priority that should be to mitigate. Then, The HOR 2 is used to determine which actions are to be done first, considering their differing effectiveness as well as resources involved and the degree of difficulties in performing. It needs to calculate the total effectiveness of each action. The formula to calculate the effectiveness is:

$$
T E k=\sum_{j} A R P j E k \quad(\forall k)
$$


where:

ARP : Aggregate Risk Priority

Ek : Relationship between risk agent and preventive action $\{0,1,3,9\}$

It needs to calculate the total effectiveness to difficulty, the formula is:

$$
E T D k=\frac{T E k}{D k}
$$

where:

ETDk : Effectiveness to difficulty ratio

TEk : Total effectiveness of action $\mathrm{k}$

Dk : Degree of difficulty performing action $\mathrm{k}$

It chooses the high ETD is the first preventive action that should be doing first.

\section{Result and Discussion}

Based on data analysis, some results are found:

\subsection{Risk Event}

Risk event is the risk that may be occurring. Risk event and the severity of the distribution process can be shown in Table 3.

Table 3. Risk event

\begin{tabular}{|c|c|c|c|c|c|}
\hline No & $\begin{array}{c}\text { Major } \\
\text { Processes }\end{array}$ & $\begin{array}{c}\text { Sub- } \\
\text { processes }\end{array}$ & Risk events & $\begin{array}{c}\mathrm{Cod} \\
\mathrm{e}\end{array}$ & $\begin{array}{l}\text { Sever } \\
\text { ity }\end{array}$ \\
\hline 1 & Plan & \multicolumn{2}{|c|}{$\begin{array}{l}\text { Scheduling the emptiness } \\
\text { stock on fuel } \\
\text { station }\end{array}$} & E1 & 5 \\
\hline \multirow[t]{5}{*}{2} & Deliver & Filling & $\begin{array}{l}\text { There is oil spill } \\
\text { and overflow }\end{array}$ & E2 & 3 \\
\hline & & & $\begin{array}{l}\text { fire and } \\
\text { explosion }\end{array}$ & E3 & 4 \\
\hline & & & $\begin{array}{l}\text { The pulling } \\
\text { clutch }\end{array}$ & E4 & 3 \\
\hline & & $\begin{array}{l}\text { Deliver } \\
\text { process }\end{array}$ & $\begin{array}{l}\text { Tardiness of } \\
\text { deliver }\end{array}$ & E5 & 2 \\
\hline & & & $\begin{array}{l}\text { Not delivery fuel } \\
\text { oil }\end{array}$ & E6 & 3 \\
\hline 3 & Return & $\begin{array}{l}\text { Handling } \\
\text { return from } \\
\text { customer }\end{array}$ & $\begin{array}{l}\text { tardiness of cross } \\
\text { ferry }\end{array}$ & E7 & 3 \\
\hline
\end{tabular}

Determining the major process is from SCOR-method then divided into three plans, deliver, and return. Each Sub process has risk event. Risk event was given by code with E1 until E7. The severity has number 1 until 5; it means minor impact until catastrophic impact.
Risk agent is the cause of the risk event. It can show the risk agent and occurrence in the distribution process in Table 4

There are nine identified risk agents. The risk agent gives a code with A code (A1 to A9). Each risk agent has occurrence from 1 to 5 . The value of occurrence means very unlikely until very probable. The occurrence rating scale is from the expert by interview.

Table 4. Risk agent

\begin{tabular}{cclc}
\hline No & Code & \multicolumn{1}{c}{ Risk Agent } & $\begin{array}{c}\text { Occurrenc } \\
\text { e }\end{array}$ \\
\hline 1 & A1 & $\begin{array}{l}\text { The failure of delivering } \\
\text { schedule }\end{array}$ & 3 \\
2 & A2 & $\begin{array}{l}\text { Fuel station not deliver stock } \\
\text { report actually }\end{array}$ & 2 \\
3 & A3 & $\begin{array}{l}\text { Error deposit via bank and } \\
\text { underpayment }\end{array}$ & 2 \\
4 & A4 & Human Error & 2 \\
5 & A5 & Not implement SOP & 1 \\
6 & A6 & Trandard Operation Process) & 3 \\
7 & A7 & Traffic accident & 5 \\
8 & A8 & Car trouble & 3 \\
9 & A9 & Negligence car tank crew & 1 \\
\hline
\end{tabular}

\subsection{Occurrence and Severity Code}

The occurrence and severity code has aims to determine the matrix of occurrence and severity to gets the minor and major impact. The severity code and occurrence code match to get the new code of $\mathrm{E}$ and $\mathrm{A}$ for put on the matrix of occurrence and severity. It aims to make a new code to determine the risk in what position - minor or major impact. It gets some code of risk agent and risk events (E1A1 until E7A9). The code can be shown in Table 5.

\subsection{Occurrence and Severity Matrix}

The occurrence and severity matrix show the minor and major impact. It can be shown in the Fig. 3 .

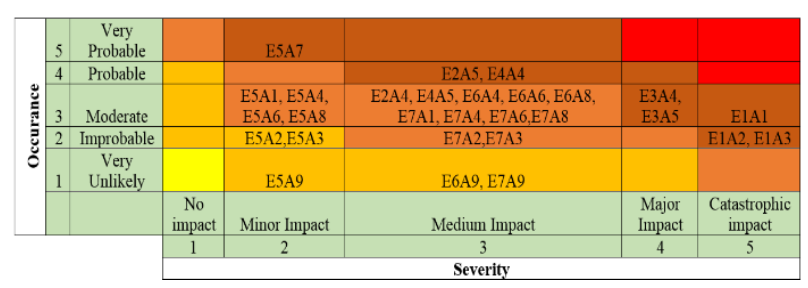

Fig. 3. Occurrence and severity matrix

From the matrix of occurrence and severity, it gets the major impact and minor impact of the risks. It is identified that E5A9 has a minor impact. It needs to eliminate the risk because it only focusses on the risk that has the major and medium impact and immediate mitigation is required.

\subsection{Risk Agent}


Table 5. Risk event and risk agent

\begin{tabular}{|c|c|c|c|c|}
\hline Code & $\begin{array}{c}\text { Seve } \\
\text { rity }\end{array}$ & $\begin{array}{c}\text { Cod } \\
\text { e }\end{array}$ & $\begin{array}{c}\text { Occurrenc } \\
\text { e }\end{array}$ & $\begin{array}{c}\text { Code } E \\
\text { and A } \\
\end{array}$ \\
\hline \multirow{3}{*}{ E1 } & \multirow{3}{*}{5} & $\mathrm{~A} 1$ & 3 & E1A1 \\
\hline & & A2 & 2 & E1A2 \\
\hline & & A3 & 2 & E1A3 \\
\hline \multirow{2}{*}{ E2 } & \multirow{2}{*}{3} & A4 & 3 & E2A4 \\
\hline & & A5 & 4 & E2A5 \\
\hline \multirow{2}{*}{ E3 } & \multirow{2}{*}{4} & A4 & 3 & E3A4 \\
\hline & & A5 & 3 & E3A5 \\
\hline \multirow[b]{2}{*}{ E4 } & \multirow{2}{*}{3} & A4 & 4 & E4A4 \\
\hline & & A5 & 3 & E4A5 \\
\hline \multirow{8}{*}{ E5 } & \multirow{8}{*}{2} & A1 & 3 & E5A1 \\
\hline & & $\mathrm{A} 2$ & 2 & E5A2 \\
\hline & & A3 & 2 & E5A3 \\
\hline & & A4 & 3 & E5A4 \\
\hline & & A6 & 3 & E5A6 \\
\hline & & A7 & 5 & E5A7 \\
\hline & & A8 & 3 & E5A8 \\
\hline & & A9 & 1 & E5A9 \\
\hline \multirow{5}{*}{ E6 } & \multirow{5}{*}{3} & A3 & 2 & E6A3 \\
\hline & & A4 & 3 & E6A4 \\
\hline & & A6 & 3 & E6A6 \\
\hline & & A8 & 3 & E6A8 \\
\hline & & A9 & 1 & E6A9 \\
\hline \multirow{7}{*}{ E7 } & \multirow{7}{*}{3} & $\mathrm{~A} 1$ & 3 & E7A1 \\
\hline & & A2 & 2 & E7A2 \\
\hline & & $\mathrm{A} 3$ & 2 & E7A3 \\
\hline & & A4 & 3 & E7A4 \\
\hline & & A6 & 3 & E7A6 \\
\hline & & A8 & 3 & E7A8 \\
\hline & & A9 & 1 & E7A9 \\
\hline
\end{tabular}

\subsection{House of Risk 1}

House of Risk is trying to relate a set of requirements (what) and a set of responses (how) where each response could address one or more requirements. It gives degree correlation such as low (one), moderate (three), and high (nine). Result House of Risk 1 can be shown in Table 6.
Table 6. House of risk 1

\begin{tabular}{|c|c|c|c|c|c|c|c|c|c|c|}
\hline \multirow{2}{*}{ No } & \multirow{2}{*}{ Risk Event } & \multicolumn{9}{|c|}{ Risk Agents } \\
\hline & & A1 & $\mathbf{A} 2$ & A3 & A4 & A5 & A6 & A7 & A8 & Si \\
\hline 1 & E1 & 3 & 3 & 9 & & & & & & 5 \\
\hline 2 & E2 & & & & 9 & 9 & & & & 3 \\
\hline 3 & $\mathbf{E 3}$ & & & & 9 & 9 & & & 9 & 4 \\
\hline 4 & $\mathbf{E 4}$ & & & & 9 & 3 & & & & 3 \\
\hline 5 & E5 & 9 & 3 & 9 & 3 & & 9 & 9 & 9 & 2 \\
\hline 6 & E6 & & & 9 & 3 & & 9 & & 3 & 3 \\
\hline 7 & E7 & 3 & 1 & 1 & 9 & & 3 & 3 & 9 & 3 \\
\hline & $\mathbf{O j}$ & 3 & 2 & 2 & 2 & 1 & 3 & 5 & 3 & \\
\hline & $\mathbf{A R P j}$ & 126 & 48 & 186 & 264 & 72 & 162 & 135 & 270 & \\
\hline & $\mathbf{P j}$ & 6 & 9 & 3 & 2 & 7 & 4 & 5 & 1 & \\
\hline
\end{tabular}

ARP (Aggregate Risk Potential) is calculated, the result is shown in Table VI. It indicates the importance of each risk agent. It is the result of the likelihood of occurrence of the risk agent $\mathrm{j}$ and the aggregate impacts generated by the risk events caused by the risk agent $\mathrm{j}$.

\subsection{Pareto Calculation}

Pareto Calculation needed to determine the number of risk agents with high-priority rank based on the ARPj, (from HOR 2). The calculation can be shown in Table 7.

Table 7. Pareto Calculation

\begin{tabular}{ccccccc}
\hline $\begin{array}{c}\text { Risk } \\
\text { Agent }\end{array}$ & Pj & ARPj & $\begin{array}{c}\text { Cum } \\
\text { ulativ } \\
\text { e } \\
\text { ARP }\end{array}$ & & \multicolumn{2}{c}{ \% ARP Cumulati } \\
ve ARP & \\
\hline A8 & 1 & 270 & 270 & $21 \%$ & $21 \%$ & \\
A4 & 2 & 264 & 534 & $21 \%$ & $42 \%$ & Priority \\
A3 & 3 & 186 & 720 & $15 \%$ & $57 \%$ & \\
A6 & 4 & 162 & 882 & $13 \%$ & $70 \%$ & \\
\hline A7 & 5 & 135 & 1017 & $11 \%$ & $81 \%$ & \\
A1 & 6 & 126 & 1143 & $10 \%$ & $90 \%$ & non- \\
A5 & 7 & 72 & 1215 & $6 \%$ & $96 \%$ & priority \\
A2 & 8 & 48 & 1263 & $4 \%$ & $100 \%$ & \\
\hline
\end{tabular}

Based on Table VII. It gets the priority and non-priority risk agent from the Pareto calculation. It calculates the ARP percentage and cumulative ARP. The Cumulative ARP above $80 \%$ is not a priority and below $80 \%$ is a priority.

Diagram Pareto is used for the show between the ARP and cumulative ARP to know what the immediate mitigation is required. By using $80 \%$ cut off based on the value of ARP, four risk agents are identified to be "prioritized risk agent", (Table 7). They are A8 (Car trouble), A4 (Human Error), A3 (Error deposit via bank 
and underpayment) and A6 (traffic accident). The diagram Pareto can be shown in Fig.4.

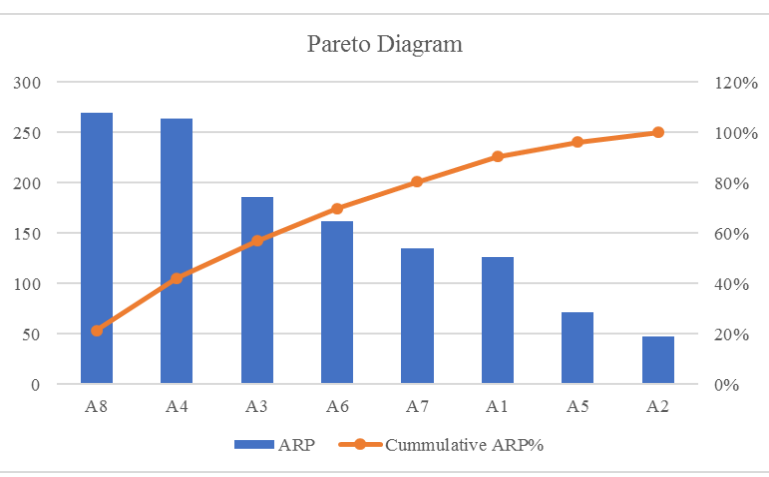

Fig 4. Pareto diagram

From the diagram, it can determine which the risk agent that should be the priority to mitigate. A8, A4, A3, and A6 become the priority that should be needed mitigation. The priority risk can be shown in Table 8 .

Table 8. Priority Risk Agent

\begin{tabular}{cccl}
\hline Risk & \multicolumn{2}{c}{ AR Cumulat } & \\
Agent & P & ive & \multicolumn{1}{c}{ Risk Agent } \\
\hline A8 & 270 & $21 \%$ & Car trouble \\
A4 & 264 & $21 \%$ & Human Error \\
& & & Error deposit via bank and \\
A3 & & $18 \%$ & underpayment \\
& 186 & $15 \%$ & traffic accident \\
\hline
\end{tabular}

After Pareto diagram, it has priority risk agent that has the ARP 270, 264, 186, and 162 . It becomes the priority to mitigate. Based on risk agent identified, an intensive discussion has been done to identify all possible action to prevent the problem. Nine preventive actions are identified Table 9.

Table 9. Preventive Action

\begin{tabular}{cll}
\hline No & Code & Preventive Actions \\
\hline 1 & PA1 & SOP socialization \\
2 & PA2 & Display SOP in the place of activity \\
3 & PA3 & $\begin{array}{l}\text { Conduct safety talk routine once every three } \\
\text { days }\end{array}$ \\
4 & PA4 & Conduct monitoring in the place of activity \\
5 & PA5 & Conduct Standard Operating Procedure \\
6 & PA6 & Conduct check car tank routine \\
7 & PA7 & Servicing regularly \\
8 & PA8 & More communicative to bank and customer \\
9 & PA9 & Reexamination of the data existing data \\
\hline
\end{tabular}

To get effective and efficient action, some important preventive actions will be selected from all possible action. HOR 2 is applied; the result is in Table 10.

Table 10. House of Risk 2

\begin{tabular}{|c|c|c|c|c|c|c|c|c|c|c|c|}
\hline \multirow[b]{2}{*}{ No } & \multirow{2}{*}{$\begin{array}{c}\text { Risk } \\
\text { Agent }\end{array}$} & \multicolumn{9}{|c|}{ Preventive Action } & \multirow{2}{*}{ ARP } \\
\hline & & PA1 & PA2 & PA3 & PA4 & PA5 & $\begin{array}{c}\text { PA } \\
6 \\
\end{array}$ & $\begin{array}{r}\mathbf{P} \\
\mathbf{A} 7 \\
\end{array}$ & $\begin{array}{c}\text { PA } \\
8 \\
\end{array}$ & $\begin{array}{c}\text { PA } \\
9 \\
\end{array}$ & \\
\hline 1 & A8 & & & 9 & 3 & 9 & 9 & 9 & & & 270 \\
\hline 2 & A4 & 9 & 9 & 9 & 9 & 9 & & & & 1 & 264 \\
\hline 3 & A3 & & & & 1 & 1 & & & 9 & 9 & 186 \\
\hline 4 & A6 & 9 & 9 & 9 & 1 & 9 & 9 & 9 & & & 162 \\
\hline $\begin{array}{r}\mathrm{T} \\
\text { Effe } \\
\mathrm{es} \\
\mathrm{A} \\
(\mathrm{T}\end{array}$ & $\begin{array}{l}\text { Total } \\
\text { ectiven } \\
\text { ss of } \\
\text { ction } \\
\text { TEk) }\end{array}$ & 3834 & $\begin{array}{c}383 \\
4\end{array}$ & 6264 & 3534 & $\begin{array}{c}645 \\
0\end{array}$ & $\begin{array}{c}388 \\
8\end{array}$ & & $\begin{array}{c}167 \\
4\end{array}$ & $\begin{array}{c}193 \\
8\end{array}$ & \\
\hline & $\begin{array}{l}\text { gree of } \\
\text { ficulty } \\
\text { formin } \\
\text { action } \\
\text { (DK) }\end{array}$ & 3 & 3 & 3 & 3 & 4 & 3 & 3 & 3 & 3 & \\
\hline & $\begin{array}{l}\text { ectiven } \\
\text { ess to } \\
\text { fficulty } \\
\text { Ratio } \\
\text { ETD) }\end{array}$ & 1278 & $\begin{array}{c}127 \\
8\end{array}$ & 2088 & 1178 & $\begin{array}{l}161 \\
2,5\end{array}$ & $\begin{array}{c}129 \\
6\end{array}$ & $\begin{array}{l}12 \\
96\end{array}$ & 558 & 646 & \\
\hline & $\begin{array}{l}\text { Rank } \\
\text { ciority }\end{array}$ & 5 & 6 & 1 & 7 & 2 & 3 & 4 & 9 & 8 & \\
\hline
\end{tabular}

Based on nine preventive actions, a mapping analysis is done by house of risk 2. An expert judgment is applied to give a rating for each relation among risk agent and preventive actions. Based on the calculation of the total effectiveness, degree of the difficulty, effectiveness to difficulty ratio, and rank priority are gained. The priority preventive action to mitigate the selected risk agents can be shown in Table 11.

Table 11. Chosen preventive action

\begin{tabular}{lllc}
\hline No & Code & \multicolumn{1}{c}{ Preventive Actions } & ETD \\
\hline 1 & PA3 & $\begin{array}{l}\text { Conduct safety talk routine once every } \\
\text { three days }\end{array}$ & 2088 \\
2 & PA5 & $\begin{array}{l}\text { Conduct Standard Operating Procedure } \\
\text { training }\end{array}$ & 1612, \\
3 & PA6 & Conduct check car tank routine & 1296 \\
4 & PA7 & Servicing regularly & 1296 \\
5 & PA1 & SOP socialization & 1278 \\
6 & PA2 & Display SOP in the place of activity & 1278 \\
7 & PA4 & $\begin{array}{l}\text { Conduct monitoring in the place of } \\
\text { activity }\end{array}$ & 1178 \\
8 & PA9 & $\begin{array}{l}\text { Examination of the data existing data } \\
9\end{array}$ & 646 \\
9 & PA8 & $\begin{array}{l}\text { More communicative to bank and } \\
\text { customer }\end{array}$ & 558 \\
\hline
\end{tabular}

The priority preventive action is from Effectiveness to Difficulty (ETD). It gets the preventive action that should 
be the priority to mitigate the risk agent. The first priority preventive action is conducting safety talk routine once every three days and followed by conducting Standard Operating Procedure training.

\section{Conclusion}

Based on the result, the conclusion from this research is:

1. The distribution process of fuel gets 7 risks events and 9 risk agent identifications.

2. From the mapping of house risk 1 gets 5 risk agents that should be used to determine the mitigation. The risk agents are trouble car tank (A8) with ARP 270, human error (A4) with ARP 264, error deposit via bank and underpayment (A3) with ARP 186, and traffic accident (A6) with ARP 162.

3. Based on house of risk 2, two most significant preventive action are conducting safety talk routine once every three days (PA3) with ETD 2088 and conducting Standard Operating Procedure training (PA5) with ETD 1612,5

\section{References}

1. L.D. Frendendall \& J, E. Hill.) Basics of Supply Chain Management, CRC, (1999)

2. J. T. Mentzer, J. S. Keebler, N. W. Nix, C. D. Smith, \& Z. G. Zacharia, Journal Of Business Logistics, Vol.22, No. 2, 1, 22(2), 1-25, (2001)

3. D. Walters, Supply Chain Risk Management. London and Philadelphia Kogan Page Limite, (2006)

4. T.C.E Cheng, F.K.Yip, A.C.L Yeung, Supply risk management via guanxi in the Chinese business context: The buyer's perspective, International Journal of Production Economics 139, 3-13, (2012)

5. Heckmann, T. Comes, S. Nicke,. A critical review on supply chain risk - Definition, measure. Omega, 121. (2014)

6. M. Giannakis, T. Papadopoulos,. Supply chain sustainability: A risk management approach. Int. J. Production Economics, 455-470. (2015)

7. G. Behzadi, M. J. O'Sullivan, T. L. Olsen, A. Zhang. Agribusiness Supply Chain Risk Management: A Review of Quantitative Decision Models. Omega, 122, (2017).

8. J. Kakeu, \& M. Bouaddi Empirical evidence of news about future prospects in the risk-pricing of oil assets, Energy Economics, 64, 458-468, (2017)

9. P. L Chu, C. Vanderghem, H. L. MacLean, B.A. Saville, Financial analysis and risk assessment of hydroprocessed renewable jet fuel production from camelina, carinata and used cooking oil, Applied Energy, 401-409, (2017)

10. X. Sun, C. Liu, X. Cheng, X. Li, Modeling systemic risk of crude oil imports: Case of China's global oil supply chain, Energy, 121, 449-465, (2017)

11. M. H. Paydar, V. Babaveisi, A. S. Safaei, An engine oil closed-loop supply chain design considering collection risk, Computers \& Chemical Engineering, 104, 38-55, (2017)
12. R. Sreedevi \& H. Saranga.. Uncertainty and supply chain risk: The moderating role of supply chain. International Journal of Production Economics, 332342. (2017)

13. N. Pujawan and L. H. Geraldin.. House of risk: a model. Business Process Management, 953-967, (2009)

14. T. Kusmantini, A.D. Guritno, \& H. Rustamaji, Mapping of Supply Chain Risk in Industrial Furniture Base on House of Risk Framework, 7(34), 104-115,.(2015)

15. B. Kristanto, B.. Aplikasi Model House of Risk ( Hor ) Untuk Mitigasi Risiko Proyek Pembangunan Jalan. Jurnal Ilmiah Teknik Industri, 13(2), 1-10, (2014)

16. M. Golparvar, \& M. Seifbarghy, Application of SCOR Model in an Oil- producing Company, 4, 59$69,(2009)$ 